\title{
Insights into the epidemiology of Pierce's disease in vineyards of Mallorca, Spain
}

\author{
E. Moralejo ${ }^{a *}$ (D), D. Borràs ${ }^{b}$, M. Gomilac, M. Montesinos ${ }^{a}$, F. Adrover ${ }^{b}$, A. Juan ${ }^{d}$, \\ A. Nieto ${ }^{\mathrm{b}}$, D. Olmo ${ }^{\mathrm{b}}, \mathrm{G}$. Seguí ${ }^{\mathrm{C}}$ and B. B. Landa

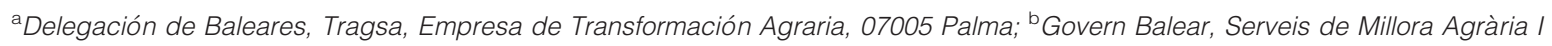 \\ Pesquera, 07009 Palma; 'Microbiology (Biology Department), University of the Balearic Islands, 07122 Palma; ' Servicio de Agricultura, \\ Conselleria de Medi Ambient, Agricultura i Pesca, 07006 Palma; and Institute for Sustainable Agriculture, Consejo Superior de \\ Investigaciones Científicas (IAS-CSIC), 14004 Córdoba, Spain
}

Xylella fastidiosa (Xf), the causal agent of Pierce's disease (PD), has long been considered a major threat to prosperous European viticulture. In May of 2017, PD was officially detected on a grapevine in Mallorca. To better understand the epidemiology of the first established outbreak of PD in Europe, the disease incidence and severity were assessed, vector transmission experiments were performed, and cultivar responses to Xf infections both in the field and in inoculation experiments were monitored. The genetic structure of $\mathrm{Xf}$ local populations was also investigated by multilocus sequence typing analysis, and their whole genome sequences and phylogenetic positions compared with respect to PD strains worldwide. Disease incidence was moderately low (0.07) and highly variable, ranging from 0.0 to 0.99 . Its economic impact on wine production was considered low. Vineyards managed under conventional viticulture were significantly less infected than organic farming. Under greenhouse conditions, the insect Philaenus spumarius efficiently transmitted the pathogen from infected to healthy grapevines. In the inoculation experiments, Xf infected, to some degree, 29 of the 30 cultivar $\times$ rootstock combinations $(n=239)$. Cultivars Viura, Gorgollasa and Sauvignon Blanc were the most susceptible ones. All Xf isolates from grapevines belonged to sequence type ST1; they phylogenetically clustered within the Californian ST1 clade, with which they shared a $99.94 \%$ identity and the same plasmid. In addition, ST1 caused almond leaf scorch disease, where notably its incidence (0.78) and severity was much higher than PD. The likely reasons for these wide differences are discussed in the context of a 20-year Xf introduction scenario.

Keywords: grapevine diseases, invasive plant pathogens, phylogenetic analysis, Pierce's disease, vector transmission, Xylella fastidiosa

\section{Introduction}

Pierce's disease (PD) of grapevines is economically important in California and limits growth of vineyards in the southeast of the USA (Bisson et al., 2002; Tumber et al., 2014). The causal agent of $\mathrm{PD}$, the bacterium Xylella fastidiosa (Xf), is a well-known polyphagous pathogen ( $>500$ hosts) associated with noteworthy crop diseases in the Americas (Almeida \& Nunney, 2015) and recently in Europe (EFSA Panel on Plant Health (PHL), 2018). Outside the American continent, there are only confirmed reports of PD in Taiwan (Leu \& Su, 1993) and Iran (Amanifar et al., 2014).

Pierce's disease was first described by Newton Pierce in 1889 in vineyards of Anaheim, southern California. The disease is transmitted by insect vectors belonging to the sharpshooter leafhoppers (Hemiptera: Cicadellinae)

*E-mail: emoralejor@gmail.com and spittlebugs (Hemiptera: Aphrophoridae). Once the pathogen is transmitted to a healthy grapevine, the bacterium colonizes and progressively occludes the xylem vessels, eventually impairing water transport (Newman et al., 2003). Symptoms similar to drought appear in midsummer, as leaves with marginal necrosis and petiole matchsticks. At the end of summer, green islands on stems are seen, together with fruit clusters shrivelled and stem tips dieback. A few years after infection, the plant may die (Thorne et al., 2006).

The Californian grape industry incurs substantial costs, estimated around \$104.4 million per year, from direct losses of vines due to PD and on efforts to mitigate disease damage (Tumber et al., 2014). Consequently, Xf has been regarded as a major threat to the European wine industry for decades, and therefore listed and subject to quarantine in the EU (European Union, 2000). Although there have been some interceptions of infected Vitis plants in the past in Europe, only a single report of an outbreak of PD was reported in Kosovo in 1997 
(Berisha et al., 1998). However, PD was declared as absent in Europe, because this field outbreak was not possible to confirm in subsequent years.

The unexpected virulence exhibited by the olive Xf strain in Italy heightened concerns about the risk of its spread within the EU, prompting urgent mandatory surveys to the member states. As a result, new cases of interceptions/introductions of Xf have been recorded in Europe (Loconsole et al., 2016; Bergsma-Vlami et al., 2017; Denancé et al., 2017). In October 2016, Xf was first found at a garden centre in Mallorca (Olmo et al., 2017). Subsequent surveys revealed the presence of three subspecies on the Balearic Islands, i.e. pauca in Ibiza, fastidiosa in Mallorca and multiplex in Mallorca and Menorca.

The strain from Mallorca of subsp. fastidiosa was characterized using multilocus sequence typing (MLST) and shown to belong to the ST1 type (Olmo et al., 2017), the same strain causing PD and almond leaf scorch disease (ALSD) in California. By the end of 2017, PD positive samples from all vineyard areas of Mallorca were confirmed at the Official Laboratory of the Plant Health department of the Balearic Islands (LOSVIB), reinforcing suspicions that Xf had long been overlooked. The probable origin of ST1 together with isolates of strain ST81 of the subspecies multiplex have been linked to an unprecedented almond tree mortality emerging around 2008 in Son Carrió, east Mallorca (Moralejo \& Belbahri, 2017).

An endemic origin of the PD pathogen around the Gulf of Mexico was assumed due to the disease severity on European Vitis vinifera varieties, compared to the greater resistance of native vines (Hewitt, 1958). However, this interpretation has been recently challenged with the use of MLST for Xf phylogenetic analysis, which indicated that PD was caused by the same clonal lineage across the USA (Schuenzel et al., 2005; Yuan et al., 2010). Furthermore, Nunney et al. (2010) provided strong evidence on the invasive origin of the PD strain based on phylogenetic analysis, whereby ST1 isolates from the USA nested within a clade with other strains of subsp. fastidiosa from Central America, where the greatest genetic diversity in the subspecies was found (Montero-Astúa et al., 2007). Knowledge on the geographic origin and current distribution of the Xf strains causing PD is critical for establishing effective quarantine measures. In this context, the origin and timing of the introduction of ST1 strain in Mallorca is a relevant plant health issue not yet resolved that needs to be addressed.

Although the Mediterranean Sea is a natural barrier to dispersal of Xf outside Mallorca, there is great concern about the risk posed to vineyards on mainland Spain and other European countries. The question of incidence and impact on grapevine in Europe is thus a very important one in terms of directing future survey efforts and research funding. To clarify the situation of the PD epidemiology in Mallorca, this study looked at the disease incidence and severity, vector transmission, and the genetic relationships of the Xf populations from Mallorca associated with PD, with other Xf strains belonging to subspecies fastidiosa causing PD and ALSD worldwide. Moreover, to determine which grapevine varieties would provide a better tolerance response to $\mathrm{PD}$, inoculation tests were conducted on different scion $\times$ rootstock combinations. Understanding key aspects of the epidemiology of PD in Mallorca will not only allow for improved control strategies, but should also help to identify, prevent and fight against the disease in other areas still free of the pathogen.

\section{Materials and methods}

\section{Field samples and surveys for field incidence and severity of PD}

After the first case of PD in May 2017, increasing numbers of grapevine samples, potentially having symptoms of $\mathrm{PD}$, were received for Xf analysis at the Official LOSVIB. Samples came from different sources, i.e. viticulturists, cooperatives, private fields and agricultural extension. Samples were labelled, registered and georeferenced before being processed following EPPO protocols (EPPO - PM 7/24 (3), 2018). Details on methods of DNA extraction and detection of Xf by real-time PCR are given below.

According to the last agriculture census, there are 2192 ha of vineyards planted in Mallorca, of which 1052 are on dry and 1140 on irrigated land (https://www.mapama.gob.es/es/estadis tica/temas/estadisticas-agrarias/agricultura/superficies-producc iones-anuales-cultivos). Among these, 595 ha are registered as organic viticulture (Directori d'Operadors, Producció Vegetal xls; http://www.cbpae.org/index.php?option=com_content\&vie $\mathrm{w}=$ article $\& \mathrm{xml}: \mathrm{id}=44 \&$ Item $\times \mathrm{ml}: \mathrm{id}=216 \& \times \mathrm{xml}:$ lang=cat $).$ To esti mate disease incidence and severity, 17 vineyards (fields) with diverse cultivar assemblages were surveyed, conducting one examination per vineyard evenly spread throughout the period from late August to October 2018. They were spread across the main wine-producing areas of the island. Of these, nine vineyards were listed as organic viticulture and the others were assigned to conventional viticulture. Henceforth, disease incidence is defined as the proportion of diseased plants in a population (Madden \& Hughes, 1995). A randomized cluster sampling design was used to obtain a direct measure of heterogeneity of disease incidence and severity of each cultivar within fields (Madden \& Hughes, 1995). Each sampling unit $(n=7)$ consisted of observations of 20 contiguous plants in a row. The viticulturist was previously consulted about the total number of plants per variety. Afterwards, seven numbers were selected using a random number generator from a mobile phone app. The different stages of characteristic PD symptoms in the field, such as leaf scorch, petiole matchsticks, green islands and shrivelled fruit, were visually identified (Newman et al., 2003). Plants were recorded as with/without symptoms, and disease severity scored for each plant as: $0=$ no symptoms; $1=1-5$ leaves scorched; $2=>5$ leaves scorched and with incidence of matchsticks; $3=$ as 2 , with green islands; and $4=$ as 3 , with shrivelled fruits and/or shoot dieback (Fig S1). To ensure accuracy in PD visual assessment, representative sample batches were analysed with qPCR in the laboratory as described below.

\section{Inoculation tests}

In March 2018, 1-year-old rootstocks grafted in winter with dormant grapevine cultivars were received from a nursery in mainland Spain (Viveros Villanueva Vides, SL). The plants were grown in $20 \mathrm{~L}$ plastic pots with a standard potting mix. Thirty 
rootstock $\times$ scion cultivar combinations were used in the inoculation assay, comprising local cultivars and foreign cultivars such as Cabernet Sauvignon, Merlot and Syrah (Table 1). The pots were randomly distributed in 12-plant rows along an insect-proof tunnel exposed to ambient temperature. Plants were daily drip-irrigated to field capacity, fortnightly sprinkled with a slow-release fertilizer and treated with insecticides and fungicides when needed until the end of the experiment. Two weeks before the onset of the inoculation assay, leaf samples of all plants were collected and tested for the presence of Xf through qPCR as described below.

For the inoculation experiment, a recently genome-sequenced isolate XLY 2055/17 of Xf subsp. fastidiosa (ST1) was used, recovered from a grapevine cv. Parellada in Manacor in August 2017 (Gomila et al., 2019). The isolate was grown on BYCE medium at $28{ }^{\circ} \mathrm{C}$ for $7-10$ days, following EPPO protocols (EPPO - PM 7/24 (3), 2018). Cells were collected by scraping the colonies and suspending them in $1.5 \mathrm{~mL}$ Eppendorf tubes, each with $1 \mathrm{~mL}$ phosphate-buffered saline (PBS) solution, until obtaining a turbid $\left(10^{8}-10^{9}\right.$ cells $\left.\mathrm{mL}^{-1}\right)$ suspension. Plants were mechanically inoculated by pin-prick inoculation (Almeida \& Purcell, 2003) with slight modifications. A $10 \mu \mathrm{L}$ drop of the bacterial suspension was pipetted onto the leaf axil and punctured five times with an entomological needle. Eight replicates per scion $\times$ rootstock combination were inoculated with the bacterial suspension, and four plants per cultivar with a drop of PBS as a control. Inoculation was repeated 2 weeks thereafter by piercing the next leaf axil above that previously inoculated (Wallis et al., 2013).

Disease severity was rated by counting the number of leaves with symptoms 8 weeks post-inoculation (WPI) and then biweekly until the 16 th week. To determine the basipetal and systemic movement of $\mathrm{Xf}$, the number of leaves with symptoms below the point of inoculation were counted from the same stems, or from any stem below, at 12 WPI. An acropetal:basipetal ratio of leaves with symptoms was calculated for each plant and cultivar $\times$ rootstock combination. Plants with and without symptoms were tested by qPCR for Xf infection at 12 WPI, taking the petiole of the second and fifth leaf above the point of inoculation. On the 14th week, five leaves per plant of all inoculated plants were used for Xf isolation, as described below. Those plants for which the qPCR was negative and Xf could not be isolated were treated as not infected. Additionally, at the end of the experiment (18 WPI) qPCR was used to check

Table 1 Severity index of different grapevine cultivar $\times$ rootstock combinations over time after inoculation with Xylella fastidiosa subsp. fastidiosa strain ST1 (XYL 2055/17).

\begin{tabular}{|c|c|c|c|c|c|c|c|c|}
\hline \multirow[b]{2}{*}{ Grapevine scion cultivar } & \multirow[b]{2}{*}{$\mathrm{R} / \mathrm{W}^{\mathrm{a}}$} & \multirow[b]{2}{*}{ Rootstock } & \multicolumn{6}{|c|}{ Time after inoculation (weeks) } \\
\hline & & & 8 & 10 & 12 & 14 & 16 & $12^{\mathrm{b}}(\%)$ \\
\hline$\overline{\text { Mandó }}$ & $\mathrm{R}$ & $110 \mathrm{R}$ & $0.67(6 / 9)^{\mathrm{c}}$ & $1.11(7 / 9)$ & $2.89(9 / 9)$ & $3.22(9 / 9)$ & $4.56(9 / 9)$ & 100.0 \\
\hline \multirow[t]{2}{*}{ Prensal } & w & $161-49$ & $0.50(4 / 8)$ & $1.38(7 / 8)$ & $2.75(8 / 8)$ & $3.63(8 / 8)$ & $4.75(8 / 8)$ & 100.0 \\
\hline & & $110 \mathrm{R}$ & $0.13(1 / 8)$ & $0.25(1 / 8)$ & $1.50(5 / 8)$ & $1.50(5 / 8)$ & $2.38(5 / 8)$ & 50.0 \\
\hline Gorgollassa & $\mathrm{R}$ & $110 \mathrm{R}$ & $1.00(5 / 7)$ & $2.14(6 / 7)$ & $4.71(7 / 7)$ & $4.86(7 / 7)$ & $5.00(7 / 7)$ & 100.0 \\
\hline Giró Negre & $\mathrm{R}$ & $110 R$ & $0.00(0 / 8)$ & $0.13(1 / 8)$ & $1.25(3 / 8)$ & $2.00(5 / 8)$ & 2.25 (5/8) & 62.5 \\
\hline Cabernet & $\mathrm{R}$ & $110 \mathrm{R}$ & $0.00(0 / 8)$ & $0.13(1 / 8)$ & $0.38(2 / 8)$ & $0.63(2 / 8)$ & $0.88(2 / 8)$ & 25.0 \\
\hline \multirow[t]{3}{*}{ Syrah } & $\mathrm{R}$ & $41 \mathrm{~B}$ & $0.00(0 / 8)$ & $0.13(1 / 8)$ & $0.63(2 / 8)$ & $0.75(2 / 8)$ & $0.88(2 / 8)$ & 12.5 \\
\hline & & $110 \mathrm{R}$ & $0.00(0 / 8)$ & $0.13(1 / 8)$ & $1.88(7 / 8)$ & $2.50(7 / 8)$ & $3.50(7 / 8)$ & 100.0 \\
\hline & & 140R & $0.44(3 / 9)$ & $0.78(4 / 9)$ & $2.11(5 / 9)$ & $2.67(5 / 9)$ & $2.89(6 / 8)$ & 55.5 \\
\hline Viognier & w & $110 \mathrm{R}$ & $0.13(1 / 8)$ & $0.13(1 / 8)$ & $0.63(3 / 8)$ & $1.13(4 / 8)$ & $2.25(5 / 8)$ & 75.0 \\
\hline \multirow[t]{5}{*}{ Tempranillo } & $\mathrm{R}$ & $110 \mathrm{R}$ & $0.25(2 / 8)$ & $0.38(2 / 8)$ & $0.88(2 / 8)$ & $1.25(3 / 8)$ & $1.75(5 / 8)$ & 25.0 \\
\hline & & $1103 \mathrm{P}$ & $1.63(7 / 8)$ & $2.33(7 / 8)$ & $3.83(7 / 8)$ & $4.17(7 / 8)$ & $4.17(7 / 8)$ & 62.5 \\
\hline & & $\mathrm{SO} 4$ & $0.13(1 / 8)$ & $0.63(3 / 8)$ & $1.88(4 / 8)$ & $2.25(4 / 8)$ & $2.38(4 / 8)$ & 50.0 \\
\hline & & $140 R$ & $1.25(4 / 8)$ & $1.50(4 / 8)$ & $2.25(4 / 8)$ & $2.38(4 / 8)$ & $2.50(4 / 8)$ & 50.0 \\
\hline & & $41 \mathrm{~B}$ & $0.25(1 / 8)$ & $0.38(2 / 8)$ & $1.13(2 / 8)$ & $1.13(2 / 8)$ & $1.25(2 / 8)$ & 25.0 \\
\hline Chardonnay & w & $110 \mathrm{R}$ & $0.13(1 / 8)$ & $0.50(3 / 8)$ & $2.13(5 / 8)$ & $2.75(5 / 8)$ & $2.63(6 / 8)$ & 75.0 \\
\hline Merlot & $\mathrm{R}$ & $110 \mathrm{R}$ & $1.00(5 / 8)$ & $2.13(6 / 8)$ & $3.51(6 / 8)$ & $3.51(6 / 8)$ & $3.75(6 / 8)$ & 75.0 \\
\hline \multirow[t]{3}{*}{ Viura } & W & $140 R$ & $0.00(0 / 10)$ & $0.10(1 / 10)$ & $2.60(7 / 10)$ & $2.80(7 / 10)$ & $3.20(7 / 10)$ & 70.0 \\
\hline & & $1103 P$ & $0.75(4 / 8)$ & $1.25(7 / 8)$ & $3.88(7 / 8)$ & $4.38(7 / 8)$ & $4.38(7 / 8)$ & 87.5 \\
\hline & & $\mathrm{SO} 4$ & $0.50(3 / 8)$ & $1.50(6 / 8)$ & $4.13(8 / 8)$ & $4.63(8 / 8)$ & $4.75(8 / 8)$ & 100.0 \\
\hline \multirow[t]{2}{*}{ Sauvignon Blanc } & w & $110 \mathrm{R}$ & $0.88(4 / 8)$ & $2.00(8 / 8)$ & $3.75(8 / 8)$ & $4.75(8 / 8)$ & $5.00(8 / 8)$ & 100.0 \\
\hline & & $\mathrm{SO} 4$ & $0.00(0 / 8)$ & $0.00(0 / 8)$ & $0.50(4 / 8)$ & $0.50(4 / 8)$ & $0.50(4 / 8)$ & 0.0 \\
\hline Vinater Blanc & W & 110R & $0.13(1 / 8)$ & $0.13(1 / 8)$ & $0.50(2 / 8)$ & $0.50(2 / 8)$ & $1.00(3 / 8)$ & 25.0 \\
\hline \multirow[t]{2}{*}{ Giró Ros } & w & $110 \mathrm{R}$ & $0.00(0 / 8)$ & $0.13(1 / 8)$ & $0.25(2 / 8)$ & $0.25(2 / 8)$ & $0.38(2 / 8)$ & 25.0 \\
\hline & & $161 / 49$ & $0.14(1 / 8)$ & $0.14(1 / 8)$ & $0.86(3 / 8)$ & $1.43(3 / 8)$ & $2.29(4 / 8)$ & 37.5 \\
\hline Esperó de Gall & $\mathrm{R}$ & $110 \mathrm{R}$ & $0.13(1 / 8)$ & $0.25(1 / 8)$ & $0.75(2 / 8)$ & $0.75(2 / 8)$ & $0.75(2 / 8)$ & 12.5 \\
\hline Callet & $\mathrm{R}$ & $110 \mathrm{R}$ & $0.00(0 / 8)$ & $0.38(2 / 8)$ & $1.50(4 / 8)$ & $1.63(4 / 8)$ & $2.25(4 / 8)$ & 37.5 \\
\hline Mancés & $\mathrm{R}$ & 110R & $0.00(0 / 8)$ & $0.00(0 / 8)$ & $0.25(2 / 8)$ & $0.25(2 / 8)$ & $0.25(2 / 8)$ & 25.0 \\
\hline Manto Negro & $\mathrm{R}$ & $110 \mathrm{R}$ & $0.13(1 / 8)$ & $0.25(1 / 8)$ & $2.88(6 / 8)$ & $3.00(6 / 8)$ & $3.75(6 / 8)$ & 75.0 \\
\hline Argamusa & w & $110 \mathrm{R}$ & $0.00(0 / 0)$ & $0.13(1 / 8)$ & $0.63(3 / 8)$ & $0.63(3 / 8)$ & $1.63(4 / 8)$ & 50.0 \\
\hline
\end{tabular}

${ }^{\mathrm{a}} \mathrm{R}$, red wine; $\mathrm{W}$, white wine.

${ }^{b}$ Combination of qPCR plus isolation.

'Severity index calculated after Su et al. (2013). Numbers in parentheses are no. of plants showing Pierce's disease symptoms/no. of plants inoculated. 
whether the bacteria had moved to the roots, i.e. by picking up fine-root samples from two (qPCR+) plants with symptoms from each cultivar.

\section{Transmission experiments}

For the transmission assays, 50 Philaenus spumarius nymphs were collected from weeds in April-May 2018. They were caged and reared to adulthood in a greenhouse on potted Argyranthemum frutescens (Asteraceae), Ocymum basilicum (Labiatae) and Foeniculum vulgare (Apiaceae) plants, which are not listed as susceptible to Xf in Europe (EFSA Panel on Plant Health (PHL), 2018). Two grapevines of cv. Tempranillo $\times 1103 \mathrm{P}$ previously inoculated with strain ST1 that had developed PD symptoms, as confirmed by qPCR, were used for the acquisition of Xf by insects for $96 \mathrm{~h}$ (acquisition access period, APP), as described by Cornara et al. (2017). Forty P. spumarius adults were divided into two groups of 20 specimens and caged for exposure to infected plants during the APP. Then insects were then transferred in eight pools of five specimens and caged on each corresponding V. vinifera 'Tempranillo' plant (qPCR-) and incubated for $96 \mathrm{~h}$ for infection (infection access period, IAP). Two controls, consisting of plants exposed to non-infected insects from the colony (five P. spumarius per plant), were included in the experiment, as well as two non-treated plants of the same cultivar. All insects were removed from plants at the end of the IAP. After 2 months, symptoms were observed and the presence of bacteria in the plants was confirmed by qPCR analysis and isolation.

\section{Isolation and identification of bacteria and plant extracts by qPCR}

Periwinkle (PWG) and BYCE culture media were prepared following the EPPO protocol (EPPO - PM 7/24 (3), 2018). Leaf samples were washed in tap water with a drop of a commercial soap. Approximately $0.5 \mathrm{~g}$ sectioned leaf petioles per plant sample were superficially disinfected by submerging for $2 \mathrm{~min}$ in a $1 \%$ bleach solution followed by a rinse in autoclaved water, soaking for $2 \mathrm{~min}$ in $70^{\circ}$ alcohol and rinsed twice in sterile water. The sterilized petioles were packed in extraction bags (Bioreba AG) with $5 \mathrm{~mL}$ of a sterile PBS solution and then squeezed in a homogenizer (Homex 6; Bioreba). Three $10 \mu \mathrm{L}$ drops of the suspension were streaked onto Petri dishes with PWG. The plates were sealed with Parafilm, inverted and incubated at $28{ }^{\circ} \mathrm{C}$ for $4-7$ days. Colonies were identified under a Leitz Wild stereomicroscope ( $\times 40$ magnification). A single colony was gently touched with a disposable plastic loop and spread over a fresh plate. Axenic cultures were obtained through three passes of streaking single colonies onto new PWG plates.

DNA extraction from plant extracts was performed using an EZNA HP Plant Mini kit (Omega-Biotek) following the manufacturer's instructions, whereas DNA extractions from bacteria and vectors were based on the CTAB protocol (EPPO - PM 7/24 (3), 2018). DNA plant extracts were tested for the presence of Xf by TaqMan probe real-time PCR using an ECO thermal cycler $\left(\mathrm{PCR}_{\max }\right)$, and two species-specific protocols (EPPO - PM $7 / 24$ (3), 2018) were used for the detection and identification of Xf (Francis et al., 2006; Harper et al., 2010). DNA from Xf subsp. pauca strain CoDiRo or the subsp. fastidiosa strain Temecula were used as positive controls. Bacterial colonies were suspended in $200 \mu \mathrm{L}$ DNase-/RNase-free water and incubated for $15 \mathrm{~min}$ at $95^{\circ} \mathrm{C}$ followed by centrifugation at $16000 \mathrm{~g}$. For vectors, single heads, with eyes removed, were homogenized in a
$2 \mathrm{~mL}$ tube with a stainless steel bead in TissueLyser II (QIAGEN). Preliminary results were further confirmed by conventional PCR assays, using species-specific primers RST31/RST33 (Minsavage et al., 1994), which yield an amplicon of 700 bp of the RNA polymerase sigma 70 factor. For MLST analysis, seven housekeeping genes (Yuan et al., 2010) were amplified using specific primers and an annealing temperature of $58{ }^{\circ} \mathrm{C}$ from either extracted plant or bacterial DNAs.

\section{Phylogenomic comparisons}

Draft and complete genomes of all Xf strains available on NCBI databases were retrieved and analysed, including the sequences of three Xf isolates from Mallorca, XYL1732/17, XYL2055/17 and IVIA 5235 (Landa et al., 2018; Gomila et al., 2019; Table S1). Xylella taiwanensis genomes were also included in the analysis as outgroup. For all genomes, ST was determined using the Xf pubMLST webpage (https://pubmlst.org/xfas tidiosa/). Genetic relatedness among ST1 isolates, measured as average nucleotide identities based on BLAST (ANIв), were calculated using JSPECIESWS (Richter et al., 2016).

A comparative genomic analysis was performed using the GET_HOMOLOGUES software described by Contreras-Moreira \& Vinuesa (2013). All genomes were annotated with PROKKA for comparison purposes (Seemann, 2014), and the protein amino acid sequences obtained were compared using the criterion of $50 \%$ similarity over $50 \%$ of coverage alignment. Core genome genes were determined with three different clustering algorithms, bidirectional best-hits (BDBH), COGTRIANGLE (COG) and ORTHOMCL (OMCL). All proteins codified by genes of the core genome present in monocopy were aligned and concatenated. Elimination of poorly aligned positions and divergent regions of protein sequences were performed with GвLOcKs (Castresana, 2000), and the phylogenetic tree was constructed with the PHYML program (Guindon et al., 2010).

\section{Data analysis}

Statistical analyses were performed using generalized linear mixed models (GLMM) and generalized linear model (GLM) with R v. 3.5.2 software ( $\mathrm{R}$ Core Team, 2018). The function GLMER was used in the R package LME4 (Bates et al., 2018) for fitting GLMMs both for the estimation of disease incidence and severity in the field and in the inoculation assays. In all tests, the response variables (i) disease incidence, with the binomial error (logit-link function) and (ii) disease severity, with the Poisson error (log-link function) were modelled. In the assessment of disease incidence and severity in the field, both models contained the categorical variable 'field' as a random factor, and 'cultivar' nested within 'field' and 'management' as fixed factors. Sampling block effects within cultivars were not significant and removed from analyses. Because ongoing research indicates Xf was locally introduced with infected almond scions grafted on seed rootstock around 1995 in Son Carrió (east Mallorca), disjunctive spatial differences in disease incidence and severity were tested for.

In the inoculation test, a within-subject (repeated measures) factorial design was performed to evaluate differences in disease severity over time among different cultivar $\times$ rootstock combinations. Cultivars $\times$ rootstock and time were treated as fixed factors and plant subjects as a random effect. The effect of the rootstocks (110R, 1103P, SO4, 140R, 161-49 and 41B) on disease expression on grafted scions was evaluated on Tempranillo, Syrah, Viura, Sauvignon Blanc, Prensal and Giró Ros. Rootstock 
and time were analysed as fixed factors and plant subjects as a random effect. Controls were excluded from the analysis, as lesions did not develop on them.

\section{Results}

\section{$\mathrm{Xf}$ detection and isolation}

Around $17 \%(n=376)$ of grapevine samples from Mallorca received by the LOSVIB from May 2017 to October 2018 tested positive for Xf in the qPCR analysis. During the same period, 132 grapevine samples were received from the islands of Formentera, Ibiza and Menorca and all tested negative. Positive samples came from vineyards of eight municipalities of Mallorca comprising 23 cultivars and a representative number was used for attempting Xf isolation. Eventually, a total of 18 isolates were obtained from 26 attempts. All isolates showed identical phenotypes with opalescent, smoothconvex colonies with entire margin. Receipt of samples was restricted to April to November due to leaf deciduousness of grapevines; however, experimentally Xf DNA could be detected from sawdust of dormant wood samples by $\mathrm{qPCR}$, providing an alternative for surveying deciduous hosts during winter.

\section{Disease incidence and severity}

Overall, 10217 plants were visually examined for Pierce's disease in 17 fields of the main wine areas, including 19 local and international grapevine cultivars. Of these, 1948 (19.1\%) vines showed characteristic PD symptoms, such as marginal necrosis, formation of matchsticks and green islands on the stems, fruit decay and retrogressive death of shoots (Fig. S1). The accuracy of the visual symptom identification was further confirmed in the laboratory, where $77 \%$ of the overall samples $(n=1119)$ were positive for Xf in the qPCR assays, including doubtful samples brought to the laboratory to confirm they were not PD symptoms.

Disease incidence differed widely among grapevine cultivars $\left(\chi^{2}=493.8, \mathrm{df}=21 ; P<0.001\right)$, ranging from 0.0 to 0.99 (Table 2 ), where red grape cultivars were $57 \%$ more prone to infection than white grape cultivars (GLM: $\chi^{2}=93.58, \mathrm{df}=1, P<0.001$ ). However, cultivar disease incidence differed within fields, with the random variable 'field' accounting for much of the observed variation (GLMM, likelihood ratio test: $P<0.001$ ). For instance, 'field 1' had an overall 0.034 disease incidence, while seven of the eight cultivars within 'field 1' showed disease incidence between 0.19 and 0.56 in other fields (Table 2). It was tested whether this variation could be explained by differences in general cultivation management practices (conventional versus organic viticulture) related mostly to weed and pest control, rather than 'field' taken as a location factor. As expected, disease incidence under conventional farming (0.07) was notably lower than those using organic viticulture (0.38) (GLMM: $\chi^{2}=53.3, \mathrm{df}=1 ; P<0.001$; Fig. 1 ), reflecting the large impact of agricultural practices on vector populations within vineyards. Because disease severity highly correlated with incidence, similar general patterns and results were found for disease severity with respect to variation among cultivars, fields and the effect of viticulture management (Fig. S2).

A greater PD incidence was predicted in vineyards closer to the hypothesized focus in Son Carrió (Moralejo \& Belbahri, 2017) due to their longer time of exposure to the pathogen. Consistent with a disease transmitted by a short-distance dispersal vector, PD incidence and severity were higher in vineyards within the $20 \mathrm{~km}$ radius from the focus compared to vineyards more than $20 \mathrm{~km}$ away (Fig. 2). However, disease incidence could be locally high, depending on weed cover management, in some of the furthest vineyards and vice versa (Table 2). Likewise, longer exposures to Xf would presumably accumulate more chronic grapevine infections and thus upper scores in the severity assessment. In agreement, significantly higher average severity (0.73) was found within the $20 \mathrm{~km}$ radius than that projected by the regression equation (severity $=0.67$; Fig. S2). Furthermore, the severity/incidence ratio was significantly higher for the $<20 \mathrm{~km}$ versus $>20 \mathrm{~km}$ (1.37) than the conventional versus organic viticulture (1.23; Fig. 2).

\section{Cultivar susceptibility in the inoculation tests}

Grapevines from 19 cultivars were inoculated in 30 unique combinations (cultivar $\times$ rootstock), of which $58.9 \%(n=239)$ developed typical PD symptoms, such as leaf marginal necrosis and matchsticks, at 16 WPI (Fig. 3). Details on the severity scores over time are given in Table 1. Eighty-nine percent of plants with symptoms tested positive for qPCR assays at 12 WPI, and in $91 \%$ of the cases Xf could be reisolated, whereas only $0.8 \%$ $(n=12)$ of the symptomless vines were qPCR positive. On the other hand, in an attempt to evaluate overall Xf systemic movement, root infections could not be detected in any of the scion $\times$ rootstock combinations at 18 WPI. All control plants tested negative.

Cultivar $\times$ rootstock combinations differed in severity score $\left(\chi^{2}=180.13, \mathrm{df}=52, P<0.001\right)$, with time after inoculation having a significant effect $\left(\chi^{2}=1456.1, \quad \mathrm{df}=27, \quad P<0.001\right) . \quad$ Disease severity increased over time, from no differences among cultivar $\times$ rootstock combinations at 8 WPI $(P=0.12)$ to large differences at 16 WPI $\left(\chi^{2}=1026.7, \quad d f=4\right.$, $P<0.001$; Fig. 4). In addition, the rate of leaf symptom development varied among cultivar-rootstock over time (cultivar-rootstock $\times$ time interactions; $\left.\chi^{2}=184.56, \mathrm{df}=116, P<0.001\right)$. It was also found that rootstock modulated scion disease expression to different degrees with significant differences among some rootstocks (Fig. S3; Fig. 5, Table 1). On average, $\mathrm{Xf}$ moved within a cane 2.6 times faster towards the apex than towards the roots when measured across all scion $\times$ rootstock combinations at 12 WPI. 
Table 2 Pierce's disease mean incidence and severity estimated on cultivars and within fields in Mallorca

\begin{tabular}{|c|c|c|c|c|}
\hline Field & Cultivar & Incidence mean \pm SE & Severity mean \pm SE & Management \\
\hline \multirow[t]{8}{*}{ Field 1} & Merlot & $0.04 \pm 0.02$ & $0.06 \pm 0.09$ & conventional \\
\hline & Tempranillo & $0.03 \pm 0.01$ & $0.06 \pm 0.08$ & conventional \\
\hline & Gorgollasa & $0.01 \pm 0.01$ & $0.01 \pm 0.04$ & conventional \\
\hline & C. sauvignon & $0.01 \pm 0.01$ & $0.01 \pm 0.02$ & conventional \\
\hline & Manto Negro & $0.03 \pm 0.01$ & $0.04 \pm 0.05$ & conventional \\
\hline & Chardonnay & $0.04 \pm 0.02$ & $0.07 \pm 0.08$ & conventional \\
\hline & Prensal & $0.05 \pm 0.02$ & $0.09 \pm 0.07$ & conventional \\
\hline & Syrah & $0.08 \pm 0.02$ & $0.08 \pm 0.06$ & conventional \\
\hline \multirow[t]{2}{*}{ Field 2} & Tempranillo & $0.00 \pm 0.00$ & $0.00 \pm 0.00$ & conventional \\
\hline & Cabernet & $0.31 \pm 0.04$ & $0.56 \pm 0.51$ & conventional \\
\hline \multirow[t]{2}{*}{ Field 3} & C. sauvignon & $0.61 \pm 0.04$ & $0.98 \pm 0.21$ & organic vitic. \\
\hline & Manto Negro & $0.56 \pm 0.04$ & $0.78 \pm 0.10$ & organic vitic. \\
\hline \multirow{3}{*}{ Field 4} & Parellada & $0.99 \pm 0.01$ & $2.10 \pm 0.49$ & organic vitic. \\
\hline & Sauvgn. Blanc & $0.55 \pm 0.04$ & $1.13 \pm 0.57$ & organic vitic. \\
\hline & Chardonnay & $0.03 \pm 0.01$ & $0.06 \pm 0.07$ & organic vitic. \\
\hline \multirow[t]{3}{*}{ Field 5} & Callet & $0.49 \pm 0.04$ & $1.37 \pm 0.42$ & organic vitic. \\
\hline & Giró & $0.72 \pm 0.04$ & $1.48 \pm 0.70$ & organic vitic. \\
\hline & Syrah & $0.81 \pm 0.03$ & $1.52 \pm 0.42$ & organic vitic. \\
\hline \multirow[t]{8}{*}{ Field 6} & Gorgollasa & $0.14 \pm 0.03$ & $0.22 \pm 0.44$ & conventional \\
\hline & C. sauvignon & $0.33 \pm 0.04$ & $0.45 \pm 0.28$ & conventional \\
\hline & Manto Negro & $0.01 \pm 0.01$ & $0.01 \pm 0.02$ & conventional \\
\hline & Callet & $0.28 \pm 0.04$ & $0.39 \pm 0.21$ & conventional \\
\hline & Viognier & $0.46 \pm 0.04$ & $0.81 \pm 0.22$ & organic vitic. \\
\hline & Chardonnay & $0.02 \pm 0.01$ & $0.03 \pm 0.04$ & conventional \\
\hline & Prensal & $0.00 \pm 0.00$ & $0.00 \pm 0.00$ & conventional \\
\hline & Syrah & $0.74 \pm 0.04$ & $1.50 \pm 0.81$ & conventional \\
\hline \multirow[t]{3}{*}{ Field 7} & Callet & $0.55 \pm 0.04$ & $1.33 \pm 0.52$ & organic vitic. \\
\hline & Chardonnay & $0.14 \pm 0.03$ & $0.28 \pm 0.17$ & organic vitic. \\
\hline & Syrah & $0.48 \pm 0.04$ & $1.03 \pm 0.67$ & organic vitic. \\
\hline \multirow[t]{4}{*}{ Field 8} & Cabernet & $0.07 \pm 0.02$ & $0.19 \pm 0.09$ & conventional \\
\hline & Callet & $0.21 \pm 0.03$ & $0.41 \pm 0.50$ & conventional \\
\hline & Macabeu & $0.15 \pm 0.03$ & $0.40 \pm 0.42$ & conventional \\
\hline & Moscatell & $0.04 \pm 0.02$ & $0.07 \pm 0.08$ & conventional \\
\hline \multirow[t]{4}{*}{ Field 9} & Gorgollasa & $0.96 \pm 0.02$ & $2.78 \pm 0.31$ & organic vitic. \\
\hline & Callet & $0.79 \pm 0.03$ & $1.65 \pm 0.29$ & organic vitic. \\
\hline & Prensal & $0.38 \pm 0.04$ & $0.77 \pm 0.31$ & organic vitic. \\
\hline & Syrah & $0.54 \pm 0.04$ & $0.99 \pm 0.26$ & organic vitic. \\
\hline \multirow[t]{3}{*}{ Field 10} & C. sauvignon & $0.16 \pm 0.03$ & $0.43 \pm 0.43$ & conventional \\
\hline & Chardonnay & $0.03 \pm 0.01$ & $0.05 \pm 0.1$ & conventional \\
\hline & Syrah & $0.06 \pm 0.02$ & $0.11 \pm 0.12$ & conventional \\
\hline \multirow[t]{4}{*}{ Field 11} & Merlot & $0.00 \pm 0.00$ & $0.00 \pm 0.00$ & conventional \\
\hline & Sauvgn. blanc & $0.00 \pm 0.00$ & $0.00 \pm 0.00$ & conventional \\
\hline & Callet & $0.00 \pm 0.00$ & $0.00 \pm 0.00$ & conventional \\
\hline & Chardonnay & $0.00 \pm 0.00$ & $0.00 \pm 0.00$ & conventional \\
\hline \multirow[t]{7}{*}{ Field 12} & Merlot & $0.00 \pm 0.00$ & $0.00 \pm 0.00$ & conventional \\
\hline & Tempranillo & $0.00 \pm 0.00$ & $0.00 \pm 0.00$ & conventional \\
\hline & Cabernet & $0.00 \pm 0.00$ & $0.00 \pm 0.00$ & conventional \\
\hline & Viognier & $0.02 \pm 001$ & $0.04 \pm 0.07$ & conventional \\
\hline & Moscatell & $0.00 \pm 0.00$ & $0.00 \pm 0.00$ & conventional \\
\hline & Prensal & $0.01 \pm 0.01$ & $0.02 \pm 0.04$ & conventional \\
\hline & Syrah & $0.00 \pm 0.00$ & $0.00 \pm 0.00$ & conventional \\
\hline \multirow[t]{2}{*}{ Field 13} & Merlot & $0.00 \pm 0.00$ & $0.00 \pm 0.00$ & organic vitic. \\
\hline & Cabernet & $0.01 \pm 0.00$ & $0.01 \pm 0.04$ & organic vitic. \\
\hline \multirow[t]{4}{*}{ Field 14} & Manto Negro & $0.06 \pm 0.02$ & $0.07 \pm 0.06$ & organic vitic. \\
\hline & Cabernet & $0.03 \pm 0.01$ & $0.02 \pm 0.04$ & organic vitic. \\
\hline & Viognier & $0.00 \pm 0.00$ & $0.00 \pm 0.00$ & organic vitic. \\
\hline & Prensal & $0.09 \pm 0.02$ & $0.15 \pm 0.15$ & organic vitic. \\
\hline \multirow[t]{2}{*}{ Field 15} & Merlot & $0.00 \pm 0.00$ & $0.00 \pm 0.00$ & conventional \\
\hline & Sauvgn. blanc & $0.00 \pm 0.00$ & $0.00 \pm 0.00$ & conventional \\
\hline
\end{tabular}

(continued) 
Table 2 (continued)

\begin{tabular}{lllll}
\hline Field & Cultivar & Incidence mean $\pm \mathrm{SE}$ & Severity mean $\pm \mathrm{SE}$ & Management \\
\hline & Chardonnay & $0.01 \pm 0.01$ & $0.01 \pm 0.02$ & conventional \\
& Syrah & $0.01 \pm 0.01$ & $0.01 \pm 0.02$ & conventional \\
& Malvasia & $0.01 \pm 0.01$ & $0.01 \pm 0.02$ & conventional \\
& Giro Ros & $0.00 \pm 0.00$ & 0.00 & conventional \\
Field 16 & C. sauvignon & $0.27 \pm 0.04$ & $0.56 \pm 0.24$ & organic vitic. \\
& Macabeu & $0.76 \pm 0.04$ & $1.91 \pm 0.45$ & organic vitic. \\
& Moscatell & $0.37 \pm 0.17$ & organic vitic. \\
& Chardonnay & $0.29 \pm 0.04$ & $0.27 \pm 0.23$ & organic vitic. \\
Field 17 & Manto Negro & $0.19 \pm 0.03$ & $0.04 \pm 0.05$ & organic vitic. \\
& Giró & $0.04 \pm 0.02$ & $0.01 \pm 0.02$ & organic vitic. \\
& Viognier & $0.01 \pm 0.01$ & $0.03 \pm 0.04$ & organic vitic. \\
& Riesling & $0.03 \pm 0.01$ & $0.04 \pm 0.06$ & organic vitic. \\
& Prensal & $0.02 \pm 0.01$ & $0.06 \pm 0.08$ & organic vitic. \\
& Syrah & $0.06 \pm 0.02$ & $0.10 \pm 0.10$ & organic vitic. \\
& & $0.10 \pm 0.03$ & &
\end{tabular}

Organic vitic., Organic viticulture; C. sauvignon, Cabernet sauvignon; Sauvgn. blanc, Sauvignon blanc; SE, standard error.
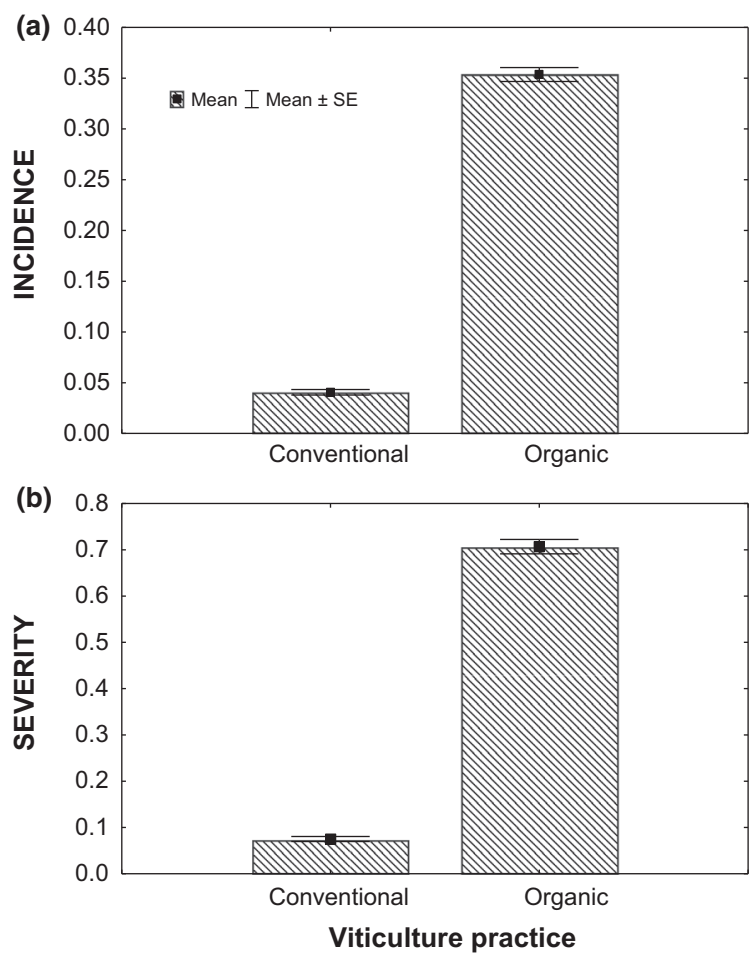

Figure 1 Differences in Pierce's disease incidence (a) and severity (b) between conventional and organic viticulture in vineyards of Mallorca. Incidence GLMM $\left(\chi^{2}=53.3, \mathrm{df}=1 ; P<0.001\right)$; severity GLMM $\left(\chi^{2}=65.6, \mathrm{df}=1 ; P<0.001\right)$. Overall, 10217 grapevines were visually examined in nine vineyards registered as organic viticulture and eight following conventional agricultural practices.

\section{Transmission experiments}

All Tempranillo plants developed PD symptoms 2 months after being exposed to infected P. spumarius, whereas the four control grapevine plants remained
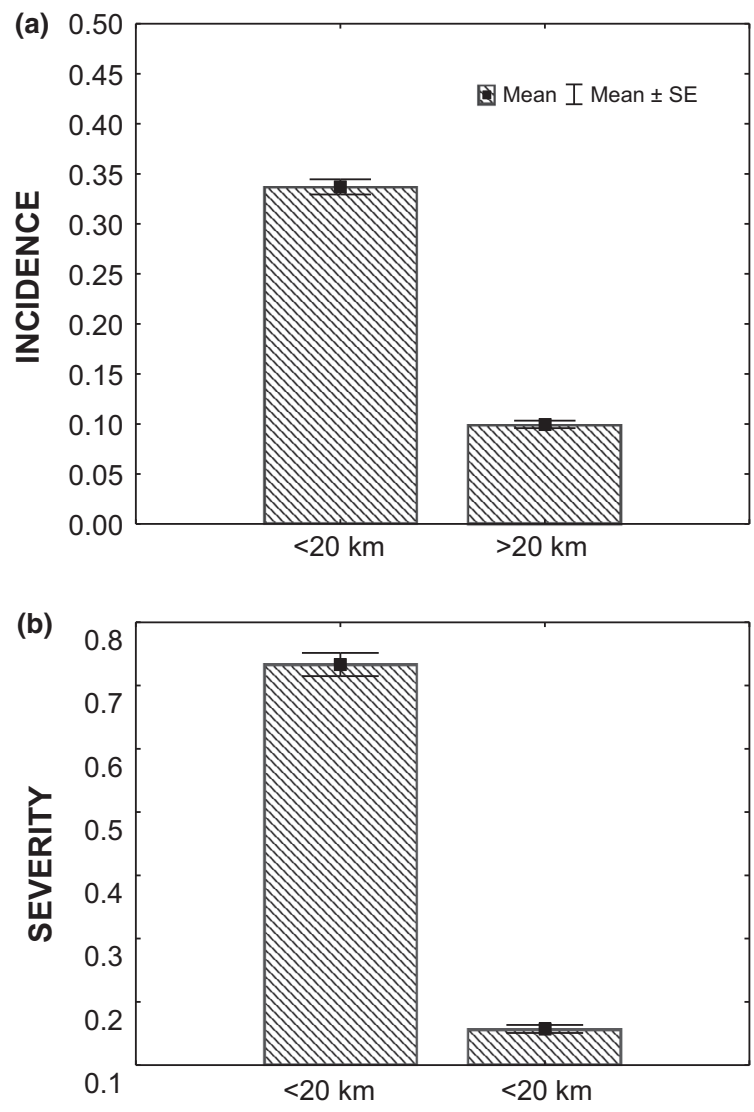

Distance from the focus

Figure 2 Differences in Pierce's disease incidence (a) and severity (b) between vineyards within and beyond a $20 \mathrm{~km}$ radius from the focus. Incidence GLM $\left(\chi^{2}=893.0, \mathrm{df}=1, P<0.001\right)$; severity GLM $\left(\chi^{2}=2067.0 ; \mathrm{df}=1, P<0.001\right)$. Each grapevine plant $(n=10217)$ was scored for disease incidence (0-1) and disease severity (0-4 scale). 

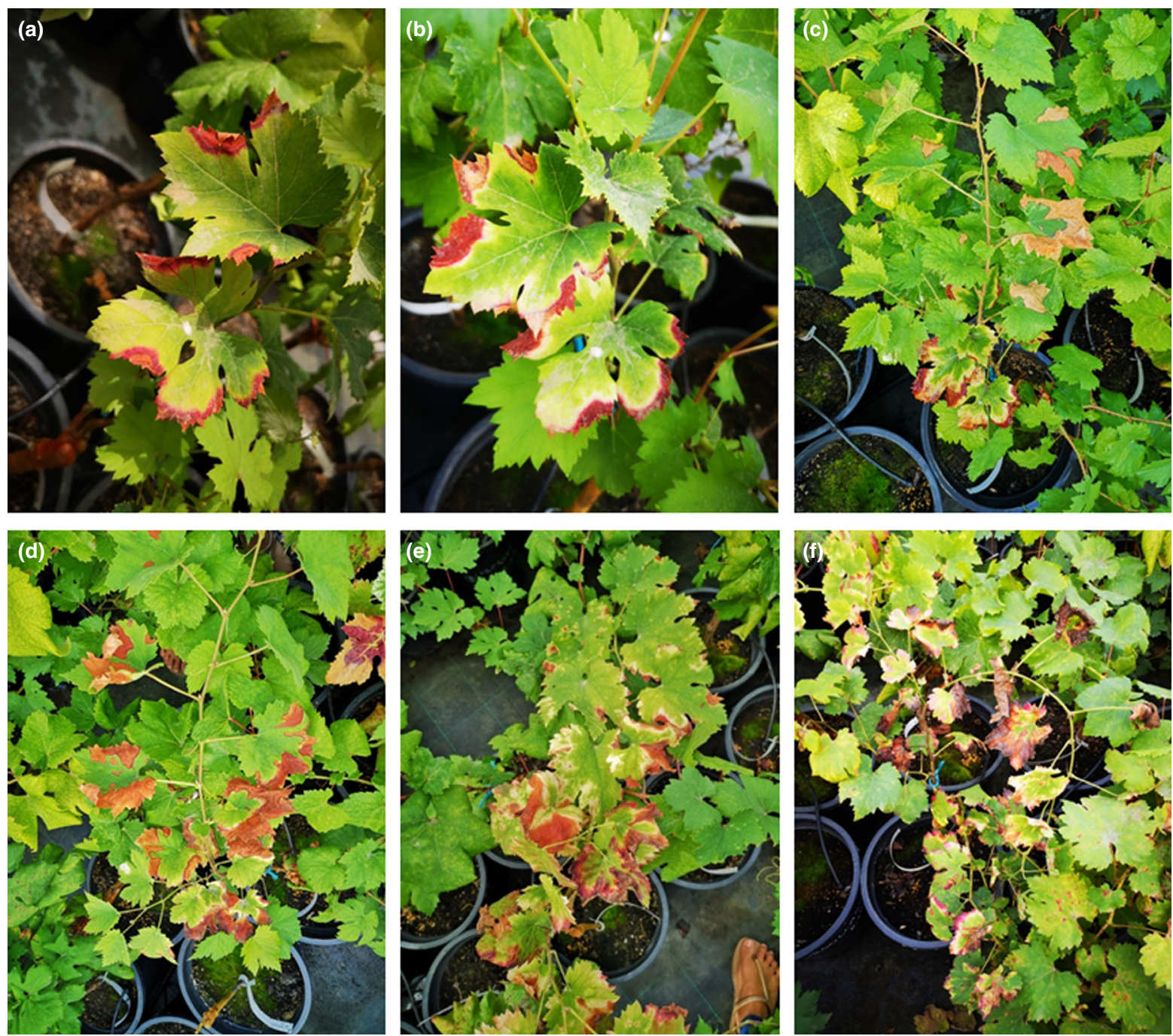

Figure 3 Development of Pierce's disease symptoms on grapevine cv. Mandó. (a) Leaf marginal necrosis 7 weeks after inoculation; (b) leaf necrosis surrounded by chlorotic tissue; (c) scorch on upper leaves following several days of rain and high relative humidity; (d) necrosis extending towards the petiole; (e) infection progressing to a vine below the point of inoculation; (f) systemic infections with canes showing matchsticks.

symptomless. Real-time PCR detected Xf both in all the infected plants and in the insects caged with the infected hosts. In contrast, no Xf was detected in the control plants nor in the insects exposed to those. The incubation period, i.e. the period from exposure of the healthy plant to infective P. spumarius until the development of PD symptoms, was between 6 and 8 weeks. Eventually, $\mathrm{Xf}$ was isolated from the eight vector-exposed infected plants, thus fulfilling Koch's postulates.

Genetic diversity of Xf subsp. fastidiosa local populations

Multilocus sequence typing analysis based on seven housekeeping gene loci assigned all isolates and DNA extracts from Xf-infected grapevines to the strain ST1 of subspecies fastidiosa. The same MLST results were obtained from Xf subsp. fastidiosa isolates causing ALSD in Mallorca and from one qPCR-positive specimen of P. spumarius. Comparison of the sequence alignments of whole genomes revealed low genetic variability among Xf isolates of strain ST1 from Mallorca. The closest genetic match $(99.94 \%$ ANIb) between isolates from Mallorca and isolates worldwide were with strains CFBP8071 and M23 of ST1 of subsp. fastidiosa both from infected almond trees in California. Genetic relatedness measured as ANIb values were of the same order both within and between isolates from populations of Mallorca and California (Table S2). As previously reported by Gomila et al. (2019), a single circular plasmid sequence of 38297 nucleotides was found in both strains XYL2055/17 and XYL1732/17, showing highest sequence similarities with the conjugative plasmids pXFAS01 (CP001012) and pXFAS_5235 

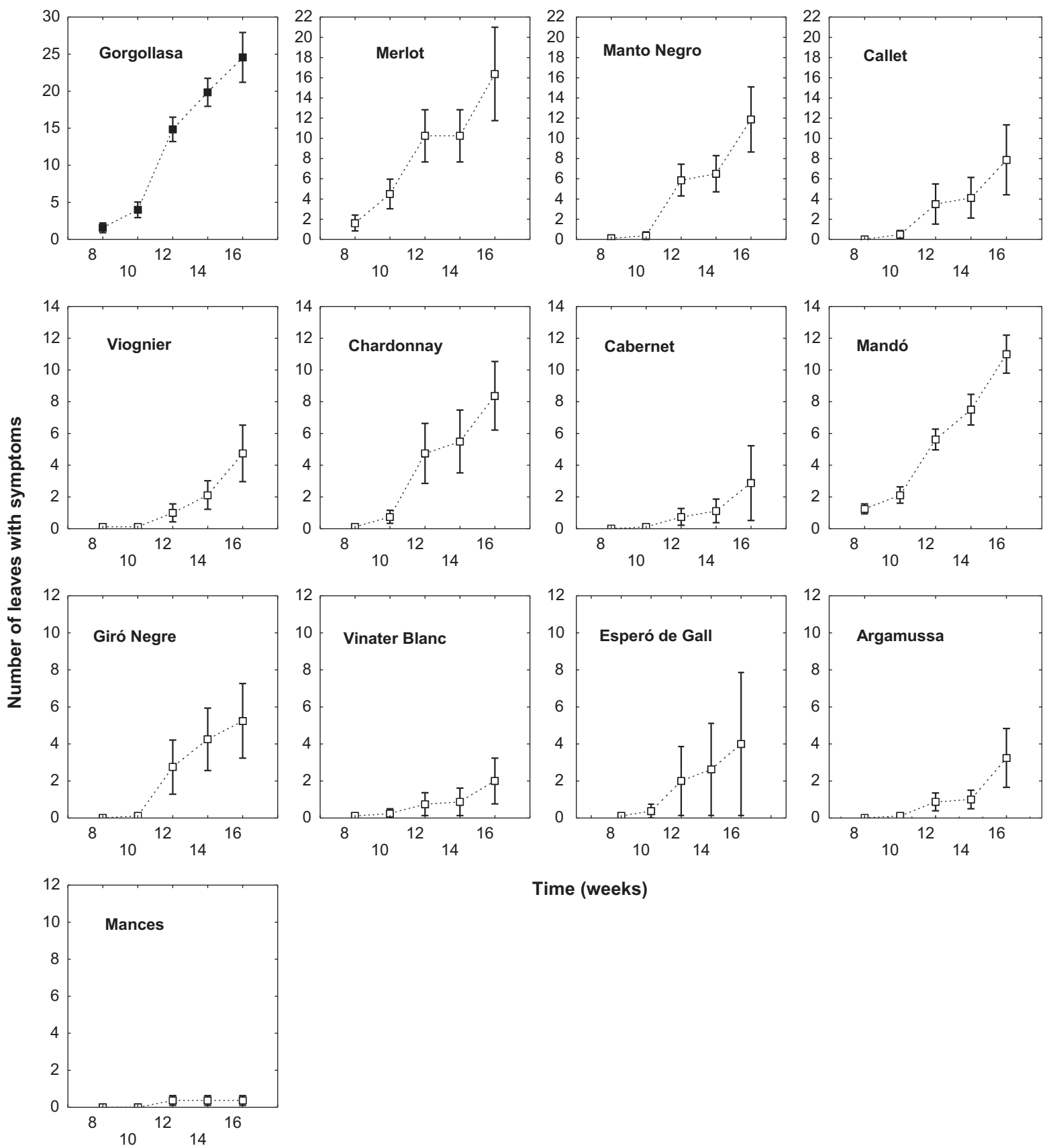

Time (weeks)

Figure 4 Progress of Pierce's disease severity over time in a selection of local and foreign grape cultivars grafted onto rootstock 110R after inoculation with strain XYL 2055/17 of Xylella fastidiosa subsp. fastidiosa (ST1). Disease severity was measured counting the number of leaves with symptoms above the point of inoculation.

(QWLC01), which were reported in Xf strain M23 (Chen et al., 2010) from almond and in Xf subsp. fastidiosa strain IVIA 5235 from cherry (Landa et al., 2018), respectively. Strain IVIA 5235 was isolated from Prunus avium in a garden centre in Mallorca that very likely became infected from neighbouring orchards affected by ALSD.

A phylogenetic tree based on the concatenation of all single-copy conserved protein sequences that make up the core genome (1286 monocopy proteins) of the 56 genomes analysed is shown in Figure 6. From the 449023 positions obtained after the concatenation of individual alignments, $97.2 \%$ of them finally were analysed (436 686 positions). The tree topology distinguished main clusters belonging to the well-known recognized subspecies, and strongly supported a close relatedness between ST1 strains from Mallorca and those from the USA, clustering PD Xf isolates from Mallorca and the 

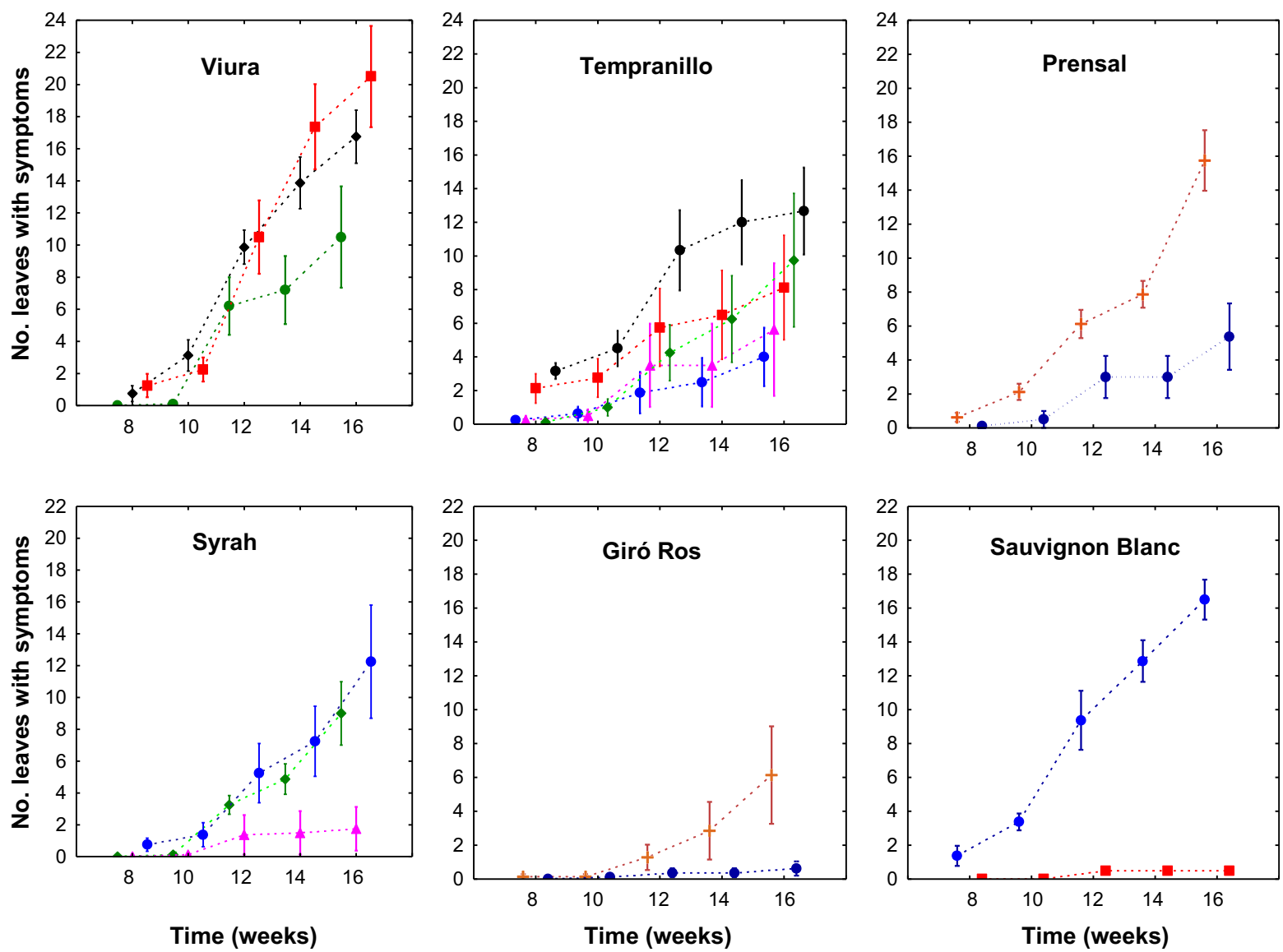

Figure 5 Effect of rootstock on Pierce's disease severity expression on different cultivars over time. Rootstocks: black circle, 1103P; red square, SO4; green diamond, 140R; blue circle, 110R; purple triangle, 41B; and orange cross, 161-49.

isolate from cherry within the same clade of PD and ALSD isolates from California (Fig. 6).

\section{Discussion}

This study gathers information aiming to fill some scientific gaps surrounding the unexpected epidemic of PD in Mallorca. Contrary to common wisdom, PD is well established in vineyards affecting almost all varieties and grapevine-growing areas, although with great heterogeneity. Considering the current knowledge on the dispersal of the insect vector P. spumarius in other Mediterranean areas (Saponari et al., 2014; Cornara et al., 2017; Cruaud et al., 2018), the widespread incidence of PD in vineyards of Mallorca precludes a recent introduction of Xf strain ST1. However, surprisingly, not only has PD had little economic impact so far on wine production (data from the Conselleria de Medi Ambient, Agricultura i Pesca) but during the last decade, damage in vineyards has remained unnoticed. These circumstantial facts somehow contradict the $19 \%$ disease-incidence assessment for 2018, which clearly represents an overestimation due to the survey bias towards organic viticulture rather than conventional farming. A much more realistic 0.07 overall incidence is obtained after weighting disease incidence according to land surface dedicated to conventional and organic viticulture. Even so, it hardly explains how PD went undetected by farmers in vineyards with such annual incidences accumulating over several years.

The winemaking industry in Mallorca and elsewhere relies on specific fruit qualities of classical and local V. vinifera varieties (Bisson et al., 2002). Although grapevine cultivars exhibited differences in disease incidence and severity both in the inoculation assays and in the field, almost all cultivars developed PD symptoms to some degree. Extensive planting of a selected number of less susceptible cultivars would indeed aid in reducing $\mathrm{PD}$, but it seems a strategy contrary to the current demands of wine consumers (Bisson et al., 2002). To avoid this problem, promising control strategies based on rootstock selection minimizing the development of symptoms or infections on the scion are being investigated (Wallis et al., 2013). In the inoculation assay here, it was found that PD severity on inoculated scions varied depending on the rootstock grafted. Future inoculation assays should target the rate of bacterial multiplication 


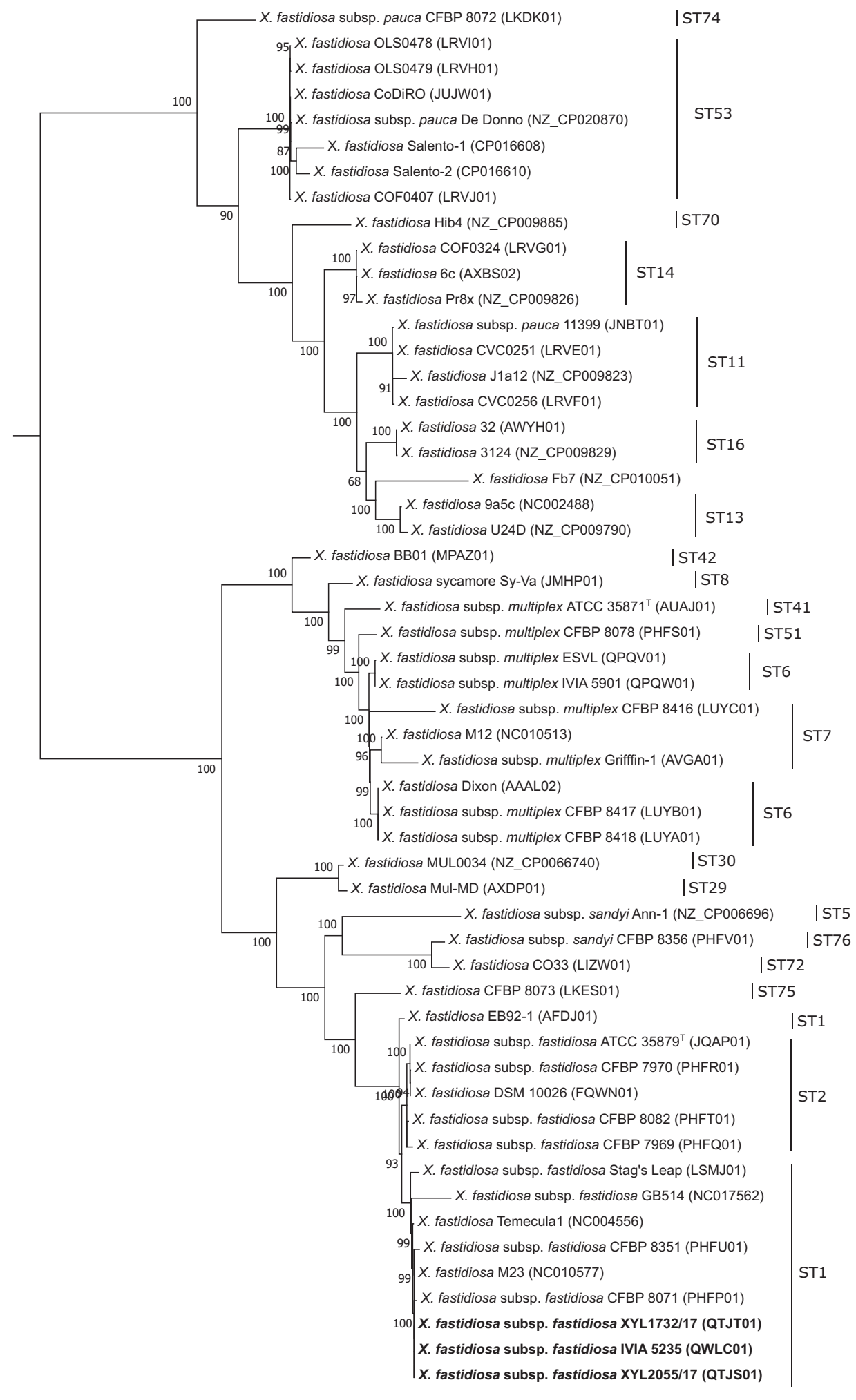

0.0050

Figure 6 Phylogenetic tree of the concatenated amino acid sequences of 1286 monocopy proteins of the core genome defined in the 56 genomes analysed belonging to species of the genus Xylella. 436686 amino acid positions out of 449023 positions of the original alignment distributed in 710 selected blocks were used to construct the tree. Strains isolated from Mallorca are labelled in bold. Accession numbers of the corresponding genomes are given in parentheses. Bootstrap values are indicated in the nodes. 
(i.e. infectivity) as well as on symptom expression within the host (i.e. tolerance), as suggested by Rashed et al. (2013).

The vector assays corroborate the effective transmission of Xf from infected grapevines to healthy ones mediated by $P$. spumarius adults, confirming previous reports of meadow spittlebug as a vector of PD in California (Severin, 1950; Cornara et al., 2016). Moreover, PD incidence was strongly correlated with weed cover within vineyards, which presumably favour the development of meadow spittlebug populations and vine-to-vine transmission. However, recent research on the landscape factors affecting the distribution of $P$. spumarius in olive groves in Italy highlights that a high proportion of vineyards managed by conventional farming practices negatively affected the vector presence (Santoiemma et al., 2019). Ongoing studies on the ecology of P. spumarius populations in vineyards and surrounding vegetation will add details on its role in Xf field transmission. Currently, the Mediterranean endemic $P$. spumarius seems to be largely the main vector of Xf in southern Italy, Corsica and the Balearic Islands (Saponari et al., 2014; Cornara et al., 2017; Cruaud et al., 2018).

Multilocus sequence typing analysis revealed that the PD epidemic in Mallorca is caused by the same clonal lineage (ST1) of Xf subsp. fastidiosa affecting vineyards in the USA (Nunney et al., 2010). It also placed the strain of the subsp. fastidiosa causing ALSD within the same population (EFSA Panel on Plant Health (PHL), 2018). The phylogenetic analysis based on core genome analysis strongly supports a US origin of the populations of strain ST1 from Mallorca, with little genetic divergence among isolates from Mallorca and California. Isolates from both continents formed a distinct cluster of genotypes with similar genetic distances dispersed throughout the whole range. Additionally, the three isolates sequenced from cherry and grape from Mallorca, and all ST1 isolates from Mallorca tested so far, harbour the same plasmid as strain M23 of Xf subsp. fastidiosa ST1 isolated from almond in California (Landa et al., 2018; Gomila et al., 2019), providing additional support to the likely Californian origin of the ST1 introduction in Mallorca. There is evidence that almond-grapevine cross-infections could be frequent, as in California (Almeida \& Purcell, 2003), because PD isolates are capable of causing ALSD when mechanically inoculated (authors' unpublished observations). Altogether, these facts suggest that the PD epidemic probably derives from an original ALSD outbreak after the introduction of the ST1 strain with infected almond scions from California, which is estimated to be around 1995 .

Although strain ST1 of Xf causes both ALSD and PD in Mallorca, disease incidence differs widely between them. Currently, the ALSD outbreak affects c. $78 \%$ of almond trees (more than 1 million trees), whereas PD incidence is generally low $(c .7 \%)$ under prevalent conventional viticulture practices, but locally high under organic farming management. While no relevant problems of vine decay or mortality were reported to the plant health authority during the last decade, by contrast, almond decline and mortality has been recognized as a huge agricultural problem in the local media since 2007. It is hypothesized that this notable difference in disease incidence and severity is associated with how both crops have been managed in the last 20 years. The probable introduction of Xf and spread of the ALSD coincided over time with the gradual abandonment of almond orchards owing to low almond prices and unproductive aging plantations, together with socioeconomic factors such as higher salaries in the tourist sector and an increasingly older farming population. This resulted in progressively less soil tillage, pest control and pruning of almond orchards at a regional scale. In addition, the emergence of almond decline was associated with the interaction between the incidence of pathogenic fungi and a drought period, altogether generating a negative feedback, prompting the abandonment of orchards. As a consequence, the surface weed cover of almond plantations steadily increased over time, which probably increased $P$. spumarius populations and thus disease spread. By contrast, the fate of the viticulture sector has taken the opposite direction since the 1990s. Investments in modern wineries and vineyards have steadily increased. Old vineyards have been substituted by new ones supported by drip irrigation systems, weeds managed by frequent ploughing, and pest control by regular insecticide treatments. Although the wine growers were unaware of the Xf problem, these management practices, sustained over time, have probably decreased P. spumarius populations and thus Xf transmission within vineyards. This explanation is consistent with the results of the field survey here, whereby managed organic vineyards showed higher incidence and severity than conventionally managed ones. The first field-established outbreak of PD in vineyards of Europe differs slightly in its general traits from those reported in the vineyards of California. The role of the endemic vector P. spumarius in the huge ALSD epidemic makes this PD outbreak somehow distinctive. Unlike vineyards in northern coastal California (Purcell \& Saunders, 1999), where riparian vegetation is an important source of infective vectors, in Mallorca there was no border effect, even in fields surrounded by almond orchards with $100 \%$ ALSD incidence (e.g. field 15, mean PD incidence $<0.01$ ). The cluster sampling method employed in this survey, intended to capture the spatial disease heterogeneity, suggests a predominant vine-to-vine spread when vector populations are high. Further specific research targeting this issue would be needed to discard other options.

The finding of PD in Mallorca exemplifies the boomerang effect of biological globalization, where plant trade enhances the risks of introductions of non-coevolved alien pathogens from different geographic origins and their accumulation over time on important crops around the world. The European grapevine was first planted in California by Father Junipero Serra, a native of Mallorca (Geiger, 2015). Two and a half centuries later, an alien pathogen established in Californian vineyards, probably 
introduced from Central America (Nunney et al., 2010), breached the European quarantine measures, paradoxically through the island of Mallorca. The good news is that despite the probable two-decade spread in Mallorca, without knowing about the presence of Xf, conventional viticulture management on the island has limited the incidence and impact of PD to moderate or low levels. Low-cost management and environmentally friendly recommendations such as weed control and soil tillage in spring may have a large impact on vector populations and thus on PD spread.

\section{Acknowledgements}

This research received financial support from the Ministry of Agriculture, Fishery and Food (Dirección General de la Sanidad de la Producción Agraria) of Spain and from 'Govern de les Illes Balears'. Part of this work was also supported by funds from the Obra Social ' $\mathrm{La}$ Caixa', Projects E-RTA2017-00004-C06-02 and ERTA2017-00004-C06-04; Programa Estatal de I+D Orientada a los Retos de la Sociedad from the Spanish Government and the Spanish State Research Agency; and Project XF-ACTORS- (Oriented Research Strategy; grant 727987) from the European Union's Horizon 2020 Framework Research Programme. The inoculation assays were performed within a greenhouse authorized by 'Direcció General d'Agricultura i Ramaderia de la Conselleria de Medi Ambient, Agricultura i Pesca del Govern de les Illes Balears'. The authors declare that they have no conflict of interest. They are very grateful for the cooperation of viticulturists and wineries of Mallorca who made the sampling for Pierce's disease possible. They are also grateful to Dr Enrique Descals for his comments on the manuscript.

\section{Data Availability Statement}

The data that are available from the corresponding author upon reasonable request.

\section{References}

Almeida RPP, Nunney L, 2015. How do plant diseases caused by Xylella fastidiosa emerge? Plant Disease 99, 1457-67.

Almeida RPP, Purcell AH, 2003. Biological traits of Xylella fastidiosa strains from grapes and almonds. Applied and Environmental Microbiology 69, 7447-52.

Amanifar N, Taghavi M, Izadpanah K, Babaei G, 2014. Isolation and pathogenicity of Xylella fastidiosa from grapevine and almond in Iran. Phytopathologia Mediterranea 53, 318-27.

Bates D, Maechler M, Bolker B et al., 2018. Ime4: Linear mixed-effects models using Eigen and S4. R package version 1.1.20. [https://CRAN. R-project.org/package=lme4]. Accessed date 18 July 2019.

Bergsma-Vlami M, van de Bilt JLJ, Tjou-Tam-Sin NNA et al., 2017. Assessment of the genetic diversity of Xylella fastidiosa in imported ornamental Coffea arabica plants. Plant Pathology 66, 1065-74.

Berisha B, Chen YD, Zhang GY, Xu BY, Chen TA, 1998. Isolation of Pierce's disease bacteria from grapevines in Europe. European Journal of Plant Pathology 104, 427-33.
Bisson LF, Waterhouse AL, Ebeler S, Walker MA, Lapsley JT, 2002. The present and future of the international wine industry. Nature 418, 696-9.

Castresana J, 2000. Selection of conserved blocks from multiple alignments for their use in phylogenetic analysis. Molecular Biology and Evolution 17, 540-52.

Chen J, Xie G, Han S, Chertkov O, Sims D, Civerolo EL, 2010. Whole genome sequences of two Xylella fastidiosa strains (M12 and M23) causing almond leaf scorch disease in California. Journal of Bacteriology 192, 4534.

Contreras-Moreira B, Vinuesa P, 2013. GET_HOMOLOGUES, a versatile software package for scalable and robust microbial pangenome analysis. Applied and Environmental Microbiology 79, 7696-701.

Cornara D, Sicard A, Zellinger AR et al., 2016. Transmission of Xylella fastidiosa to grapevine by the meadow spittlebug. Phytopathology 106, 1285-90.

Cornara D, Saponari M, Zellinger AR et al., 2017. Spittlebugs as vectors of Xylella fastidiosa in olive orchards in Italy. Journal of Pest Science 90, 521-30.

Cruaud A, Gonzalez AA, Godefroid M et al., 2018. Using insects to detect, monitor and predict the distribution of Xylella fastidiosa: a case study in Corsica. Scientific Reports 8, 15628.

Denancé N, Legendre B, Briand M et al., 2017. Several subspecies and sequence types are associated with the emergence of Xylella fastidiosa in natural settings in France. Plant Pathology 66, 1054-64.

EFSA Panel on Plant Health (PHL), 2018. Updated pest categorisation of Xylella fastidiosa. EFSA Journal 16, 5357.

EPPO - PM 7/24 (3), 2018. Xylella fastidiosa. EPPO Bulletin 48, 175218.

European Union, 2000. Council Directive 2000/29/EC of 8 May 2000 on protective measures against the introduction into the Community of organisms harmful to plants or plant products and against their spread within the Community. Official Journal of the European Communities Legislation L169 43, 1-112.

Francis M, Lin H, Cabrera-La Rosa J, Doddapaneni H, Civerolo EL, 2006. Genome-based PCR primers for specific and sensitive detection and quantification of Xylella fastidiosa. European Journal of Plant Pathology 115, 203-13.

Geiger M, 2015. The Mallorcan contribution to Franciscan California. The Americas 4, 141-50.

Gomila M, Moralejo E, Busquets A et al., 2019. Draft genome resources of two strains of Xylella fastidiosa XYL1732/17 and XYL2055/17 isolated from Mallorca vineyards. Phytopathology 109, 222-4.

Guindon S, Dufayard JF, Lefort V et al., 2010. New algorithms and methods to estimate maximum-likelihood phylogenies: assessing the performance of PhyML 3.0. Systematic Biology 59, 307-21.

Harper SJ, Ward LI, Clover GRG, 2010. Development of LAMP and real-time PCR methods for the rapid detection of Xylella fastidiosa for quarantine and field applications. Phytopathology 100, 1282-8.

Hewitt BM, 1958. The probable home of Pierce's disease virus. American Journal of Enology and Viticulture 9, 94-8.

Landa BB, Velasco-Amo MP, Marco-Noales E et al., 2018. Draft genome sequence of Xylella fastidiosa subsp. fastidiosa strain IVIA5235, isolated from Prunus avium in Mallorca Island, Spain. Microbiology Resource Announcements 7, e01222-18.

Leu LS, Su CC, 1993. Isolation, cultivation, and pathogenicity of Xylella fastidiosa, the causal bacterium of pear leaf scorch disease in Taiwan. Plant Disease 77, 642-6.

Loconsole G, Saponari M, Boscia D et al., 2016. Intercepted isolates of Xylella fastidiosa in Europe reveal novel genetic diversity. European Journal of Plant Pathology 146, 85-94.

Madden LV, Hughes G, 1995. Plant disease incidence: distributions, heterogeneity, and temporal analysis. Annual Review of Phytopathology 33, 529-64.

Minsavage GV, Thompson CM, Hopkins DL et al., 1994. Development of a polymerase chain reaction protocol for detection of Xylella fastidiosa in plant tissue. Phytopathology 84, 456-61. 
Montero-Astúa M, Hartung JS, Aguilar E et al., 2007. Genetic diversity of Xylella fastidiosa strains from Costa Rica, São Paulo, Brazil, and United States. Phytopathology 97, 1338-47.

Moralejo E, Belbahri L, 2017. X. fastidiosa associated with extensive mortality of almond trees in Mallorca. In: Book of Abstracts of the European Conference on Xylella fastidiosa: Finding Answers to a Global Problem. European Food Safety Authority and others. Palma de Mallorca 13-15 November 2017, 41 pp. [https://www.efsa.europa.e u/sites/default/files/event/171113/171113_book-of-abstracts.pdf]. Accessed 19 July 2019.

Newman KL, Almeida RPP, Purcell AH, Lindow SE, 2003. Use of a green fluorescent strain for analysis of Xylella fastidiosa colonization of Vitis vinifera. Applied and Environmental Microbiology 69, 731927.

Nunney L, Yuan X, Bromley R et al., 2010. Population genomic analysis of bacterial plant pathogen: novel insight into the origin of Pierce's disease of grapevine in the US. PLOS ONE 5, e15488.

Olmo D, Nieto A, Adrover F et al., 2017. First detection of Xylella fastidiosa infecting cherry (Prunus avium) and Polygala myrtifolia plants, in Mallorca Island, Spain. Plant Disease 101, 1820.

Purcell AH, Saunders SR, 1999. Fate of Pierce's disease strains of Xylella fastidiosa in common riparian plants in California. Plant Disease 83, 825-30.

R Core Team, 2018. R: A Language and Environment for Statistical Computing. R Foundation for Statistical Computing, Vienna, Austria. [http://www.R-project.org/]. Accessed 17 July 2019.

Rashed A, Kwan J, Baraff B et al., 2013. Relative susceptibility of Vitis vinifera cultivars to vector-borne Xylella fastidiosa through time. PLoS ONE 8, e55326.

Richter M, Rosselló-Mora R, Glöckner FO, Peplies J, 2016. JSpeciesWS: a web server for prokaryotic species circumscription based on pairwise genome comparison. Bioinformatics 32, 929-31.

Santoiemma G, Tamburini G, Sanna F et al., 2019. Landscape composition predicts the distribution of Philaenus spumarius, vector of Xylella fastidiosa, in olive groves. Journal of Pest Science 92, 1101-9.

Saponari M, Loconsole G, Cornara D et al., 2014. Infectivity and transmission of Xylella fastidiosa by Philaenus spumarius (Hemiptera: Aphrophoridae) in Apulia, Italy. Journal of Economic Entomology 107, 1316-9.

Schuenzel EL, Scally M, Stouthamer R, Nunney L, 2005. A multigene phylogenetic study of clonal diversity and divergence in North American strains of the plant pathogen Xylella fastidiosa. Applied and Environmental Microbiology 71, 3832-9.
Seemann T, 2014. Prokka: rapid prokaryotic genome annotation. Bioinformatics 30, 2068-9.

Severin HHP, 1950. Spittle-insect vectors of Pierce's disease virus. II. Life history and virus transmission. Hilgardia 19, 357-76.

Su CC, Chang CJ, Chang CM et al., 2013. Pierce's disease of grapevines in Taiwan: isolation, cultivation and pathogenicity of Xylella fastidiosa. Journal of Phytopathology 161, 389-96.

Thorne TE, Stevenson JF, Rost TL, Labavitch JM, Matthews MA, 2006. Pierce's disease symptoms: comparison with symptoms of water deficit and the impact of water deficits. American Journal of Enology and Viticulture 57, 1-11.

Tumber KP, Alston JM, Fuller KB, 2014. Pierce's disease costs California \$104 million per year. California Agriculture 68, 20-9.

Wallis CM, Wallingford AK, Chen J, 2013. Grapevine rootstock effects on scion sap phenolic levels, resistance to Xylella fastidiosa infection, and progression of Pierce's disease. Frontiers in Plant Science 4, 502.

Yuan X, Morano L, Bromley R et al., 2010. Multilocus sequence typing of Xylella fastidiosa causing Pierce's disease and oleander leaf scorch in the United States. Phytopathology 100, 601-11.

\section{Supporting Information}

Additional Supporting Information may be found in the online version of this article at the publisher's web-site.

Figure S1. Pierce's disease symptoms on grapevines observed in several fields in Mallorca. (a) Leaf scorch on cv. Macabeu with petioles forming matchsticks, severity index $(\mathrm{SI})=2$; (b) leaf margin necrosis with purple halo on a red variety (cv. Callet), $\mathrm{SI}=1$; (c) green islands, $\mathrm{SI}=3$; and (d) fruit shrivelled on cv. Chardonnay, stem dieback and systemic infection, $\mathrm{SI}=4$.

Figure S2. Correlation between Pierce's disease incidence and severity in the field; severity $=-0.0246+(2.1095 \times$ Incidence $), \quad r=0.95368$. Each point represents the mean incidence and severity of one cultivar in which a cluster random sampling $(n=140)$ was performed. Overall, 10217 grapevines were examined in 17 fields across Mallorca.

Figure S3. Basipetal and acropetal movement of Xylella fastidiosa through the cane of different scion $\times$ rootstock combinations, 12 weeks after inoculation.

Table S1. List of genomes of Xylella used in this study, ST, origin, host plant and accession number.

Table S2. Average nucleotide identities based on BLAST (ANIb) and calculated using JSPECIESWS. 